\title{
KAJIAN BUKU
}

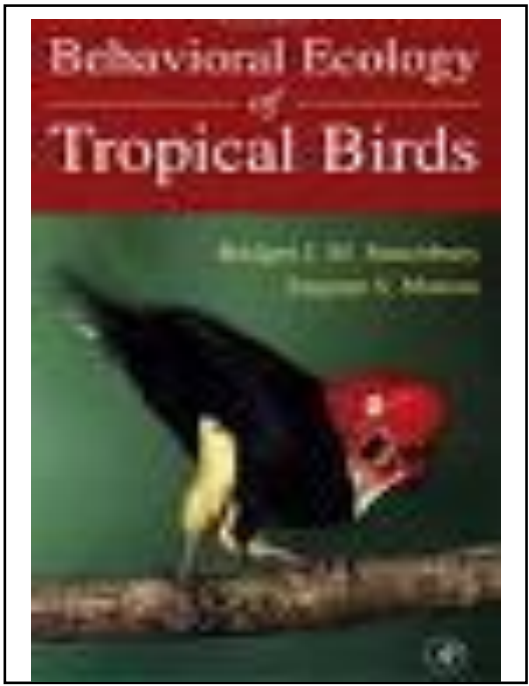

Judul Buku

Pengarang

Tahun terbit

Penerbit

Halaman

ISBN

Harga
: Behavioral Ecology of Tropical Birds

: Bridget J.M. Stuchbury and Eugene S. Morton

: 2001

: Academic Press

: 165

: $\quad 0.12 .67555 .8$

: $\$ 43.95$

\section{Menggugat Bias Temperate dalam Ekologi Perilaku Burung}

\section{Ign. Pramana Yuda}

Fakultas Teknobiologi, Universitas Atma Jaya Yogyakarta, Yogyakarta 55281

E-mail: pramyd@mail.uajy.ac.id

Daerah tropis memiliki keanekaragaman jenis yang tinggi, misalnya saja lebih kurang $80 \%$ jenis burung petengger (passerine bird) hidup dan berbiak di daerah tropis. Namun barangkali belum banyak yang mengetahui bahwa beberapa teori dalam biologi dan ekologi burung lebih banyak didasarkan pada pengamatan empirik dan pemodelan yang menggunakan jenis burung dari daerah beriklim sedang (temperate). Hal ini tidak terlepas dari persebaran ahli yang sebagian besar terkonsentrasi dan melakukan penelitian di daerah tersebut baik Eropa maupun Amerika Utara. Celakanya, pola perilaku burung, misalnya, yang ditemukan di daerah tersebut selama ini telah dianggap sebagai norma perilaku umum untuk semua jenis burung. Apakah jenis-jenis burung di daerah tropis mengikuti norma perilaku umum tersebut?
Stuchbury dan Morton dalam bukunya ini tidak sepakat dengan pendapat tersebut. Di dukung dengan bukti-bukti empirik dari beberapa penelitian jenis burung tropis, terutama di tropis Amerika Selatan, mereka menemukan bahwa dalam banyak hal jenis burung tropis berbeda dengan burung temperate. Perbedaan-perbedaan tersebut tidak terlepas dari perbedaan dasar dalam adaptasi perilaku, yaitu adaptasi perilaku jenis-jenis burung tropis merupakan hasil seleksi karena tekanan biotik (terutama interaksi dengan tumbuhan), sementara jenis burung temperate lebih karena tekanan abiotik (terutama iklim).

Lebih lanjut untuk mendukung pendapatnya, Stuchbury dan Morton secara detil dalam bab-bab yang terpisah menjabarkan beberapa adaptasi perilaku burung tropis: musim berbiak, extra-pair mating system (EPM), teritorial, komunikasi dan interaksi 
biotik, yang ternyata juga saling berkait satu dengan lainnya. Berbeda dengan burung temperate yang musim berbiaknya sangat terbatas (2-3 bulan) dan tergantung pada musim, musim berbiak burung tropis jauh lebih lama (4 - 8 bulan) dan tergantung pada ketersediaan makanan (misalnya buah). Kondisi ini menjadi salah satu penjelasan tingginya extra-pair mating pada burung temperate.

Extra-pair Mating System (EPM), yakni terjadinya 'perselingkungan' pada pasangan burung yang sebagian besar mengikuti sistem monogami, dianggap sebagai norma umum pada burung. Pandangan ini didasarkan pada hasil penelitian dengan menggunakan pendekatan molekuler yang menguak rahasia tingginya praktek perilaku perselingkuhan pada jenis-jenis burung temperate. Namun, hasil penelitian sejenis pada jenis-jenis burung tropis ternyata tidak mendukung temuan tersebut. EPM nampaknya tidak umum dianut oleh burung tropis yang monogami. Oleh karena jumlah jenis burung tropis lebih banyak, maka penulis buku ini berpendapat sebaliknya: EPM bukanlah norma umum pada burung. Musim berbiak yang pendek (2-3 bulan) di daerah temperate dipercaya menjadi pemicu tingginya tingkat EPM pada jenis burung temperate. Sebaliknya di daerah tropis, masa berbiak yang lebih panjang ( $4-8$ bulan) tidak menimbulkan perilaku sejenis.

Contoh lain tentang bias temperate adalah hubungan antara level testoteron pada burung jantan dan pertahanan teritorial. Temuan pada burung dari musim sedang yang digunakan sebagai norma umum: bahwa level testoteron yang tinggi pada burung jantan menjadi penentu keberhasilan dalam mempertahankan teritori dan dalam menarik burung betina. Level testoteron burung jantan tinggi pada saat menjelang berbiak dan turun pada saat memelihara anak. Sekali lagi kondisi ini tidak berlaku bagi burung tropis. Level testoteron burung jantan tetap rendah sepanjang musim berbiak. Kondisi burung temperate tersebut ternyata tekait dengan EPM, masa berbiak yang tinggi menyebabkan level testoteron yang tinggi karena 'diperlukan' untuk bisa melakukan EPM!

Perilaku teritori dan komunikasi pada burung temperate nampaknya juga hasil adaptasi terjadinya EPM. Kicauan burung temperate, terutama burung jantan karena yang betina tidak berkicau, lebih sering frekuensinya dalam upaya tidak hanya untuk mempertahankan teritori berbiaknya tetapi terutama sebagai upaya untuk mencegah dan menghalau burung jantan tetangganya yang selalu berusaha untuk 'mengawini' pasangannya.

Sistem teritori burung tropis juga lebih beragam. Bahkan ditemukan juga burung betina berkicau dan mempertahankan teritorinya. Teritori burung tropis tidak terbatas hanya musim berbiak, tetapi hampir sepanjang tahun dalam rangka memepertahankan akses ke sumber pakannya.

Kasus-kasus yang menjadi contoh dalam buku ini sebagian besar bersumber pada hasil penelitian di daerah tropis Amerika Selatan dan beberapa dari burung tropis Afrika dan Australia. Apakah pola tersebut berlaku juga untuk tropis Asia Tenggara? Penelitianpenelitian sejenis di kawasan Asia Tenggara sangatlah diperlukan untuk mejawab pertanyaan tersebut. 